\title{
UPAYA MENINGKATKAN KEMAMPUAN MENULIS LAPORAN KARYA WISATA DENGAN MENERAPKAN METODE TUGAS INDIVIDUAL SISWA KELAS VIIIF SEKOLAH MENENGAH PERTAMA NEGERI 3 TABANAN TAHUN PELAJARAN 2012/2013
}

\author{
Oleh : \\ Ni Made Sueni \\ Ni Wayan Sri Eka Wahyuni
}

\begin{abstract}
Teaching Indonesian should comprise a set of skills. One of the skills is a report writing skill through direct observation in the classroom. It can be seen, from the preliminary observation, that the students have difficulty in writing the report. This happens because the teachers do not give students the chance to work alone. This study is aimed to describe the increasing ability in writing skills by applying individual task of VIIIF Grade Student of Sekolah Menengah Pertama Negeri 3 Tabanan in academic Year 2012/2013. This research was conducted at Sekolah Menengah Pertama Negeri 3 Tabanan with study subjects was 50 people of VIII F grade students. At the beginning of the study it was showed that $50 \%$ of students received less than 70 which are used as the standard minimum of completeness per individual. The result in pre cycle was 65.80 then in the first cycle increased with an average value of 72.20, and in the second cycle increased to 85. Thus, through the method of writing individual task, ability of the student in writing field trip report was increased.
\end{abstract}




\section{PENDAHULUAN}

Menulis laporan karya wisata merupakan salah satu media bahasa Indonesia ragam formal dalam bentuk tulisan. Oleh karena itu, bahasa Indonesia yang digunakan harus sesuai dengan aturan atau kaidah yang berlaku.

Keterampilan berbahasa Indonesia terdiri atas empat aspek yaitu keterampilan menyimak, berbicara, membaca dan menulis. Keempat aspek tersebut saling berkaitan sehingga tidak akan mungkin pengajarannya terlepas sama sekali satu dengan yang lainnya (Tarigan,1986:1). Penga-jaran bahasa Indonesia berpolakan pada pendekatan komunikatif. Artinya, siswa dituntut pula mampu menggunakan bahasa Indonesia dengan baik dan benar sesuai dengan kaidah-kaidah yang berlaku, terutama yang digunakan dalam forum resmi atau formal, baik dalam bentuk lisan maupun tertulis.

Sejak pelajaran Bahasa Indonesia tercantum dalam kurikulum, sub pelajaran keterampilan menulis sudah diajarkan. Itu berarti, keterampilan menulis telah diajarkan sejak lama dengan pendekatan yang berbeda-beda sesuai dengan kurikulum. Ketika pelajaran bahasa Indonesia menggunakan kurikulum 1968 dan 1975, pembelajaran menulis diajarkan dengan pendekatan struktural. Demikian juga ketika pembelajaran bahasa Indonesia berdasarkan kurikulum 1994, yang dilaksanakan dengan pendekatan komunikatif. Dalam kurikulum berbasis kompetensi pun pembelajaran menulis mendapat tempat yang cukup dalam pembelajaran. Oleh karena itu, peneliti tertarik untuk meneliti masalah menulis khususnya menulis laporan karya wisata.

Dengan hal di atas, maka berdasarkan penjajakan awal yang dilakukan di Sekolah Menengah Pertama Negeri 3 Tabanan bahwa kemampuan siswa dalam menulis laporan ternyata masih kurang, yaitu dengan nilai rata -rata di bawah 70 yaitu 65,80 . Hal ini kemungkinan terjadi karena siswa merasa bosan dan kurang bersemangat mengikuti pembelajaran, suasana pembelajaran kurang mendukung atau kekeliruan dalam menerapkan metode pembelajaran. Dalam pembelajaran bahasa Indonesia, guru lebih banyak berteori dan kurang memberikan kesempatan kepada siswa untuk lebih banyak berlatih di dalam menggunakan bahasa Indonesia, khususnya menulis laporan.

Berdasarkan kenyataan ini, maka peneliti tertarik untuk meneliti masalah tersebut dengan judul "Upaya Meningkatkan Kemampuan Menulis Laporan Karya Wisata Dengan Menerapkan Metode Tugas individual Siswa Kelas VIII F Sekolah Menengan Pertama Negeri 3 Tabanan Tahun Pelajaran 2012/2013. Yang menjadi masalah dalam Penelitian ini adalah Seberapa besarkah peningkatan kemampuan menulis laporan karya wisata siswa kelas VIIIF Sekolah Menengah Pertama Negeri 3 Tabanan tahun pelajaran 2012/2013 setelah menerapkan metode tugas individual? Tujuan penelitian ini adalah untuk mengetahui/ mendeskripsikan peningkatan kemampuan menulis laporan karya wisata siswa kelas VIII F Sekolah Menengah Pertama Negeri 3 Tabanan tahun pelajaran 2012/2013 setelah menggunakan metode tugas individual.

\section{METODE PENELITIAN}

Penelitian ini termasuk penelitian tindakan kelas yang bermaksud untuk meningkatkan kemampuan menulis laporan karya wisata siswa kelas VIIIF Sekolah Menengah Pertama Negeri 3 Tabanan melalui metode tugas individual. Tindakan yang dilakukan adalah menulis laporan karya wisata melalui metode tugas individual.

Penelitian tindakan kelas ini menggunakan rancangan model kemmis yang terdiri dari 4 langkah yaitu perencanaan, pelaksanaan, observasi, dan refleksi. Penelitian ini dilakukan dalam dua siklus dengan rancangan tindkan seperti berikut.

Rancangan penelitian tindakan kelas :

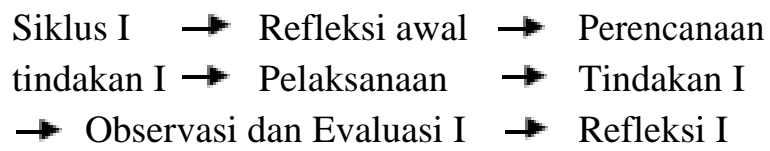

Siklus II $\rightarrow$ Perencanaan tindakan II Pelaksanaan Tindakan II $\rightarrow$ Observasi dan Evaluasi II $\rightarrow$ Refleksi Siklus II Memutuskan Tindakan terbaik.

Data penelitian ini dikumpulkan dengan metode tes/ tugas dan observasi. Tes/ tugas digunakan untuk mendapatkan data tentang kemampuan menulis laporan karya wisata siswa. 
Sedangkan observasi digunakan untuk mendapatkan data tentang perhatian dan perilaku siswa dalam proses pembelajaran.

Aspek-aspek yang dinilai dalam menulis laporan karya wisata adalah sebagai berikut.

Tabel 1. Aspek-aspek Penilaian

\begin{tabular}{|c|l|c|}
\hline NO & \multicolumn{1}{|c|}{ Aspek-aspek yang dinilai } & Bobot \\
\hline 1 & $\begin{array}{l}\text { Keruntutan dan kelengkapan isi } \\
\text { laporan }(5 \mathrm{~W}+1 \mathrm{H})\end{array}$ & 25 \\
\hline 2 & $\begin{array}{l}\text { Bahasa laporan menarik dan } \\
\text { mudah dipahami }\end{array}$ & 25 \\
\hline 3 & Sistematika laporan & 25 \\
\hline 4 & Ketepatan ejaan & 25 \\
\hline \multicolumn{2}{|c|}{ Jumlah } & $\mathbf{1 0 0}$ \\
\hline
\end{tabular}

Observasi dilakukan langsung dalam proses pembelajaran. Hal-hal yang di observasi adalah sebagai berikut.

Tabel 2. Hal-hal yang diobservasi

\begin{tabular}{|c|l|}
\hline NO & \multicolumn{1}{|c|}{ Aspek-aspek yang dinilai } \\
\hline 1 & $\begin{array}{l}\text { Perilaku dan sikap siswa dalam } \\
\text { menerima pelajaran }\end{array}$ \\
\hline 2 & Perhatian siswa dalam pembelajaran \\
\hline 3 & Motivasi siswa dalam pembelajaran \\
\hline 4 & Kreativitas siswa selama pembelajaran \\
\hline 5 & Interaksi dalam pembelajaran \\
\hline
\end{tabular}

Setelah data terkumpul, kemudian dianalisis dengan metode analisis deskriptif. Langkah-langkah dalam menganalisis data adalah:

1. Menetukan Skor Maksimal Ideal (SMI)

2. Mengubah skor mentah menjadi skor standar. Teknik yang digunakan adalah dengan mengversikan skor mentah ke dalam pedoman konversi PAP Skala 100

3. Membuat pedoman konversi

Tabel 3. Pedoman konversi PAP Skala 100 (dalam persen/\%)

\begin{tabular}{|c|c|}
\hline Tingkat Penguasaan & Skor Standar \\
\hline $95 \%-100 \%$ & 100 \\
\hline $85 \%-94 \%$ & 90 \\
\hline $75 \%-84 \%$ & 80 \\
\hline $65 \%-74 \%$ & 70 \\
\hline $55 \%-64 \%$ & 60 \\
\hline $45 \%-54 \%$ & 50 \\
\hline $35 \%-44 \%$ & 40 \\
\hline $25 \%-34 \%$ & 30 \\
\hline $15 \%-24 \%$ & 20 \\
\hline $5 \%-14 \%$ & 10 \\
\hline $0 \%-4 \%$ & 0 \\
\hline
\end{tabular}

Berdasarkan hitungan di atas, maka dapatlah ditentukan skor standar yang diperoleh oleh masingmasing siswa. Rentangan skor mentah dan skor standar yang digunakan untuk mengukur kemampuan menulis laporan karya wisata adalah seperti tabel berikut.

Tabel 4. Rentangan Skor Mentah dan Standar

\begin{tabular}{|c|c|}
\hline Skor Mentah & Skor Standar \\
\hline $95-100$ & 100 \\
\hline $85-94$ & 90 \\
\hline $75-84$ & 80 \\
\hline $65-74$ & 70 \\
\hline $55-64$ & 60 \\
\hline $45-54$ & 50 \\
\hline $35-44$ & 40 \\
\hline $25-34$ & 30 \\
\hline $15-24$ & 20 \\
\hline $5-14$ & 10 \\
\hline $0-4$ & 0 \\
\hline
\end{tabular}

Standar ketuntasan minimal per individu yang diberlakukan di Sekolah Menengah Pertama Negeri 3 Tabanan adalah 70 dan tuntas secara klasikal adalah $75 \%$.

\section{HASIL PENELITIAN DAN PEMBAHASAN}

\section{Hasil Penelitian}

\section{Hasil Penelitian Sebelum Tindakan}

Tindakan ini dilakukan dengan memberikan tugas kepada siswa untuk membuat laporan karya wisata. Tugas tersebut diperiksa kemudian dianalisis, dengan perolehan nilai tertinggi 80 dan nilai terendah 55. Nilai rata-rata kelas yang diperoleh adalah 65,80 dengan kategori cukup (belum tuntas). Itu berarti, dari 50 orang siswa baru 25 orang $(50 \%)$ yang memiliki standar ketuntasan minimal, dan sisanya perlu dicarikan alternatif pembelajaran yang bisa meningkatkn kemampuan siswa.

\section{Hasil Penelitian Tindakan Siklus I}

Pada siklus I ini, siswa diberikan tugas menulis laporan karya wisata dengan menerapkan metode tugas individual. Berdasarkan analisis data, diperoleh hasil bahwa nilai tertinggi diperoleh oleh 7 orang siswa dengan skor standar 80 dan terendah 
adalah 60 diperoleh oleh 17 orang siswa. Nilai ratarata kelas yang diperoleh adalah 72,20 . Dengan demikian, terjadi peningkatan 6,4 (12,8\%). Hasil tersebut belum memenuhi kriteria ketuntasan secara klasikal yang telah ditentukan.

\section{Hasil Penelitian Tindakan Siklus II}

Prosedur tindakan siklus II sama dengan yang dilakukan pada siklus I, hanya lebih ditekankan pada penyempurnaan hasil tindakan siklus I. Pada siklus II ini, nilai tertinggi yang diperoleh siswa adalah 90 , diperoleh oleh 25 orang siswa, nilai 80 diperoleh oleh 25 orang siswa, tidak ada siswa yang memperoleh nilai di bawah ketuntasan minimal. Nilai rata-rata yang diperoleh siswa adalah 85,00 dengan kategori baik sekali(semua tuntas).

Hasil observasi pada siklus II ini adalah dengan metode tugas individual siswa lebih fokus pada pekerjaannya, suasana pembelajaran lebih serius, reaksi siswa lebih postif dan siswa lebih aktif melakukan aktivitasnya.

\section{Pembahasan}

Berdasarkan hasil penelitian yang telah dilakukan, ditemukan bahwa pembelajaran yang menggunakan metode tugas individual dapat meningkatkan kemampuan siswa dalam menulis laporan karya wisata. Hal ini terbukti dari hasil yang diperoleh pada prasiklus adalah dengan ratarata 60,80 , pada siklus II meningkat menjadi 72,20, kemudian pada siklus II semua siswa dikatakan tuntas dengan rata-rata nilai yang diperoleh siswa adalah 85 peningkatannya cukup siginifikan. Dengan metode tugas individual, siswa menjadi lebih serius belajar dan lebih aktif melakukan tugasnya.

\section{SIMPULAN}

Berdasarkan analisis hasil dan pembahasan yang dilakukan di atas, dapat disimpulkan bahwa penerapan metode tugas individual dapat meningkatkan kemampuan siswa dalam menulis laporan karaya wisata. Hal ini terbukti dari hasil yang diperoleh selalu mengalami peningkatan dari siklus ke siklus berikutnya. Perolehan nilai rata-rata dari pra siklus 60,80 , kemudian pada siklus I meningkat menjadi 72,20, pada siklus II meningkat lagi menjadi 85. Dengan hasil tersebut disarankan kepada guru-guru pengajar bahasa Indonesia agar menggunakan metode yang tepat dalam pembelajaran sesuai dengan karakteristik materi yang diajarkan. Di samping itu, variasi metode pembelajaran perlu diterapkan untuk mencapai hasil yang maksimal.

\section{DAFTAR PUSTAKA}

Agung, A.A. Gede.(1999). Pengantar Evaluasi Pendidikan. Singaraja: STKIP Singaraja.

Arikunto, Suharsimi. (1992). Prosedur Penelitian Suatu Pendekatan Praktek. Bandung: Bina Aksara.

Aryana. (2006). Kurikulum Berbasis kompetensi; Konsep, Karakteristik dan Implementasi. Bandung: Rosda.

Depdiknas. (2006). Kurikulum Tingkat Satuan Pendidikan. Jakarta : Departemen Pendidikan Nasional.

Hamid, St. TT. Kamus Pintar Bahasa Indonesia. Surabaya: Pustaka Dua

Hadi, Sutrisno. (1996). Statistik Dasar. Jakarta: Gajah Mada Press.

Nurkencana dan Sumartana. (1986). Evaluasi Pendidikan. Surabaya: Usaha Nasional.

Purnamadewi, Indah. (2011). Upaya Meningkatkan Kemampuan Menulis Laporan Studi Banding Dengan Media Foto Berseri Melalui Metode Tugas Individual Siswa Kelas VIII A SMP Negeri 1 Tabanan Semester Ganjil Tahun Pelajaran 2010/2011. (Skripsi). Tabanan: IKIP Saraswati Tabanan

Utari, Ni Made Dwi. (2010). Upaya Meningkatkan Kemampuan Menggunakan Bahasa Indonesia Yang Baik Dan Benar Dalam Menulis Surat Dinas

Siswa Kelas VIII H Sekolah Menengan Pertama Negeri 1 Kediri Tabanan Semester Ganjil Tahun Pelajaran 2010/2011. (Skripsi). Tabanan: IKIP Saraswati Tabanan. 
